Meta

Journal des traducteurs

Translators' Journal

\title{
Problems Caused by Word Order when Interpreting / Translating from English into Japanese: The Effect of the Use of Inanimate Subjects in English
}

\section{Hiromichi Uchiyama}

Volume 36, numéro 2-3, juin 1991

URI : https://id.erudit.org/iderudit/004516ar

DOI : https://doi.org/10.7202/004516ar

Aller au sommaire du numéro

Éditeur(s)

Les Presses de l'Université de Montréal

ISSN

0026-0452 (imprimé)

1492-1421 (numérique)

Découvrir la revue

Citer cet article

Uchiyama, H. (1991). Problems Caused by Word Order when Interpreting / Translating from English into Japanese: The Effect of the Use of Inanimate Subjects in English. Meta, 36(2-3), 404-413. https://doi.org/10.7202/004516ar
Résumé de l'article

Une des difficultés les plus importantes pour un traducteur ou un interprète anglais-japonais est l'utilisation en anglais de sujets inanimés qui accomplissent des actes intentionnels. En anglais, on emploie couramment de telles constructions, alors qu'en japonais il est difficile d'imaginer un sujet inanimé en train d'accomplir une action consciente. Les interprètes ou traducteurs anglais-japonais doivent donc être en mesure d'interpréter de telles phrases anglaises pour qu'elles correspondent à la perception japonaise. On ébauche une méthode pour résoudre ce problème : la conversion des sujets inanimés de la phrase anglaise en locution adverbiale ou proposition japonaise dans le but de réduire le niveau de difficulté de maniement de la phrase. On donne des exemples pratiques de l'utilisation de cette méthode. La même méthode est aussi pertinente pour la formation des interprètes et des traducteurs, car elle peut être présentée comme un moyen de surmonter un problème courant en interprétation et en traduction anglais-japonais. 


\title{
PROBLEMS CAUSED BY WORD ORDER WHEN INTERPRETING / TRANSLATING FROM ENGLISH INTO JAPANESE: THE EFFECT OF THE USE OF INANIMATE SUBJECTS IN ENGLISH
}

\author{
HIROMICHI UCHIYAMA \\ University of Queensland, St Lucia, Australia
}

RÉSUMÉ

Une des difficultés les plus importantes pour un traducteur ou un interprète anglaisjaponais est l'utilisation en anglais de sujets inanimés qui accomplissent des actes intentionnels. En anglais, on emploie couramment de telles constructions, alors qu' en japonais il est difficile d' imaginer un sujet inanimé en train d' accomplir une action consciente. Les interprètes ou traducteurs anglais-japonais doivent donc être en mesure d'interpréter de telles phrases anglaises pour qu' elles correspondent à la perception japonaise.

On ébauche une méthode pour résoudre ce problème: la conversion des sujets inanimés de la phrase anglaise en locution adverbiale ou proposition japonaise dans le but de réduire le niveau de difficulté de maniement de la phrase. On donne des exemples pratiques de l'utilisation de cette méthode.

La même méthode est aussi pertinente pour la formation des interprètes et des traducteurs, car elle peut être présentée comme un moyen de surmonter un problème courant en interprétation et en traduction anglais-japonais.

\section{ABSTRACT}

One of the most significant difficulties facing an English-Japanese interpreter or translator is the use in English of inanimate subjects which perform intentional acts. While this is a fairly common construction in English, the Japanese normally find it difficult to conceive of an inanimate subject performing a conscious act. English-Japanese interpreter/translators therefore need to be able to interpret such English sentences so that they correspond to the Japanese perception.

This paper outlines one method of dealing with this problem - the conversion of the inanimate subjects in the English sentence into an adverbial phrase or clause in Japanese. This serves to reduce the level of difficulty in handling a sentence with a modifying clause the subject of which is inanimate. Practical examples of the use of this method are given.

This method also has relevance for interpreter/translator training, as it can be presented to students as a possible means of overcoming a common problem in EnglishJapanese interpreting and translation.

\section{INTRODUCTION}

The difference in word order between English and Japanese is a cause of major problems in interpreting/translating in such areas as speed, retention, and naturalness. This paper aims primarily to highlight one of the most significant difficulties an EnglishJapanese interpreter/translator is faced with - the effect of the use of inanimate subjects 
which perform intentional acts. It will also investigate how to deal with such inanimate subjects in terms of transforming "the surface structure of an English sentence" (Chomsky 1965:16) into the one that suits the process of interpretation/translation into Japanese.

\section{Some major characteristics of Japanese syntax as contrasted to English syntax are:}

(1) the position of the predicate or verb which occurs after the object or the complement, and accordingly at the end of the sentence (whereas in English it precedes the object or the complement);

(2) the position of a modifying word, phrase, or clause which precedes the word modified: a dependent clause precedes a principal clause (whereas in English the modified word precedes a modifying clause).

Accordingly, when interpreting/translating from English into Japanese, the verb in the English sentenceconstruction - subject - verb - object - needs to be remembered until the object has been dealt with so as to conform to Japanese sentence structure subject - object - verb.

This process becomes even more hazardous when the subject or the object in the original sentence is qualified by a modifying clause as below:

(a) A shortage of seats ${ }^{\mathrm{Ml}}$ [which limited the number $S$

of Japanese tourists who are able to make the trip]

prevented even more spectacular increase ${ }^{\mathrm{M} 2}$ [that would $\mathrm{V}$

$\mathrm{O}$

have created even more employment opportunities.]

The structure of the above sentence (a) is

$\mathrm{S}[\mathrm{M} 1]-\mathrm{V}-\mathrm{O}[\mathrm{M} 2]$.

In order to transform it into the equivalent Japanese structure

[M1]S - [M2] O - V,

the following procedures must be undertaken:

(i) the subject needs to be put aside temporarily until the output of the modifying clause (M1) which qualifies it has been completed.

(ii) the object needs to be put temporarily aside until the output of the modifying clause (M2) which qualifies it has been completed.

(iii) the verb needs to be put aside until (i) and (ii) above have been completed.

In practice, this transformation process is too complex, and therefore places too great a burden, not only on the interpreter/translator, but also on the listener/reader.

A better solution to the problems posed by inanimate subjects in English is therefore necessary. An alternative is probably to output the subject first, and then the M1, so as to follow the order of the original sentence, and thus the order of the original speaker's thought pattern. Luckily this sentence allows us to carry that out because of the nature of the subject of the sentence: while it is inanimate, it performs an action or instigates a process. But before discussing how that can be done, let us look at why an inanimate subject is so special in Japanese interpretation. 
II. In English, one very commonly attributes actions to inanimate subjects. A telephone, for example, can wake one up; a stone can break a window, etc. However, the Japanese normally find it difficult to conceive of an inanimate subject as performing or undertaking a conscious act of will or action of its own volition, or instigating a process. Thus, to take a simple example, while an English speaker may say,

"The telephone woke up the baby."

the Japanese would express the same idea as:
"Denwa de
akachan ga okita."
Because of the telephone, the baby woke up.

It should be noted that the verb in the English sentence is transitive, whereas in the Japanese sentence, which has no object, it is intransitive. The subjects of transitive verbs in Japanese are usually animate. In Japanese, transitive verbs are used only in situations where the act is wholly volitional. They are used when the speaker is conscious of a subject's act or action as exerting control on or over an external object. The Japanese sentence needs to be constructed so as to make it correspond with the Japanese perception.

To take another example, an English speaker may say,

"Japan's sharply increased investment in Australia will invite opposition to it on the part of some Australians."

The Japanese would express the same idea as:

(1) "Osutoraria ni okeru nippon no kyugekina toshi no zodai ni yotte*, osutoraria-jin no naka ni hanpatsu ga okoru."

English equivalent: "Because of Japan's rapid investment expansion, opposition to it will occur on the part of some Australians."

(*'ni yotte' corresponds with 'because of')

Alternatively,

(2) "Osutoraria de nippon kara no toshi ga kyugeki ni nobitara*, osutoraria-jin no naka ni hanpatsu ga okoru."

English equivalent: "If Japan's investment in Australia increases sharply, opposition to it will occur on the part of some Australians."

(*tara' corresponds with 'if')

Actually, the English sentence quoted above was part of a passage used in an aptitude test for entry into our course in Japanese interpreting and translation. Candidates were required to sight-translate the passage into good, natural Japanese. They were given a certain amount of time for preparation. During that time they were free to consult dictionaries and to make notes. The object of this test was to assess the candidates' accuracy, felicity and fluency of sight-translation.

The following are samples of translations given by the candidates. I will briefly discuss the translations of the candidates to demonstrate the types of problems caused by the presence of inanimate noun phrases.

A: Nihon kigyo no osutoraria ni okeru kyuzo-shite iru toshi katsudo wa ichibu no osutorariajin no hantai o maneku. 
English equivalent: Rapidly increasing investment activities by Japanese enterprises in Australia will invite opposition from some Australians.

B: Nihon no kyugekini fuete kita osutoraria de no toshi wa osutoraria no aru bubun kara hanno o maneku.

English equivalent: Japan's sharply increased investment in Australia will invite a reaction from some sections of the Australian community.

C: Osutoraria de no nihon no ohaba no zoka-shite iru toshi wa osutoraria-jin no naka de teiko o maneku.

English equivalent: Japan's increasing large-scale investment in Australia will invite resistance from some Australians.

D: Nihon ga kyugekini osutoraria ni toshi-suru koto ga osutoraria-jin no hantai ni au.

English equivalent: Japan's investing with a rapid advance in Australia will be met with opposition from Australians.

E: Nihon no subayai osutoraria ni okeru zoshi wa osutoraria-jin no ichibu ni hantai o kau.

English equivalent: The rapid increase in investments in Australia by Japan will cause opposition on the part of some Australians.

F: Kyugekini fueta osutoraria e no toshi ga osutoraria-jin no ichibu e hanpatsu o maneku.

English equivalent: Sharply increased investment that is directed to Australia will invite opposition from some Australians.

Candidates D, E, and F are Japanese native speakers. Interestingly, none of the translations present the way the Japanese would normally express the original idea as indicated in samples (1) and (2).

All candidates have a similar approach to the translation, that is, a direct translation from English into Japanese, retaining the syntactic structure of the original sentence. The use of the subject/topic indicators $w a$ and ga shows that the subject of the original sentence was identified as being the subject in each of the Japanese translations.

However, there are two aspects of D's translation which distinguish it from the others: firstly the paraphrasing of the inanimate subject into a predicate form. If we translate the paraphrased part back into English, it means "Japan's move of investing with a rapid advance in Australia." By using this predication D tried to humanise the inanimate subject in the English sentence.

Another aspect is the use of the intransitive verb "au" which means "to be faced". So the overall meaning of D's version is "Japan's investing with a rapid advance in Australia will be met with opposition from Australians". The effect of doing this is to remove the combination of an inanimate subject performing intentional acts from the Japanese sentence.

Candidate A's translation is also an interesting example of an attempt to avoid the use of an inanimate subject performing actions from Japanese by humanising it. If we translate A's translation back into English, we see that the sentence actually changes in meaning.

Hence both $\mathrm{A}$ and $\mathrm{D}$ are unconsciously aware of the unnaturalness of translating inanimate noun phrases directly into Japanese. However, they did not have the skills to overcome the problem. 
In the following sections, I will propose a technique which English-Japanese interpreters could adopt when faced with similar situations.

III. In his article "Techniques in Japanese to English and English to Japanese translation," Tomii (1988: 181) states:

"This (non-volitional subject) sentence structure is quite common in English but does not exist in Japanese."

I cannot agree that the non-volitional subject does not exist in Japanese, for I have detected numerous examples even in classical Japanese literary works of nearly one thousand years ago ${ }^{1}$ as well as countless cases found readily among modern literary works. But I consider that the examples in the ancient literary works have resulted from the strong influence of Chinese literary style, and in the modern works they arise from the influence of English.

This leads me to believe that the linguistic concept of inanimate subject performing intentional acts is not indigenous to Japan, but is a foreign rhetoric, which has never subsequently been fully assimilated into the Japanese perception. There are many aspects that consequently need research including a theoretical definition of the validity of the concept of an inanimate subject performing intentional acts, as applied to the various types of sentences.

What about the use of the inanimate subjects in English? One Japanese scholar, Kondo $^{2}$ (1986: 2) writes:

"One salient feature of English syntax, although often neglected by native speakers of English (and of other European languages) is a frequent and almost unlimited use of inanimate entities (things, time, space, collectives, abstract concepts etc.) as subjects for verbs that indicate intentional acts. To treat these uses as peripheral to mainstream English constructions fails to reflect an important characteristic of English, especially as viewed from the vantage point of a Japanese speaker."

He goes on to analyse the semantic role of the subjects as discussed by Quirk, Greenbaum, Leech \& Svartrik (1985). I am indebted to Kondo's paper (1986) for bringing the following three passages from this work to my attention. The following is from the section referring to the definition of the term "agentive":

"The AGENTIVE/NONAGENTIVE contrast is illustrated by: 'John was thinking' and 'the sun was shining.' The first is agentive, in contrast to the second, because it implies that the subject refers to an agent or 'doer' of the action. The 'doer' is typically human, and is the deliberate or self-activating initiator of the action. To some extent, the agentive/nonagentive boundary is unclcar; but agentive situation types are by definition dynamic rather than stative" (Quirk et al. 1985: 207).

Later they describe the semantic role of a subject as agentive:

"The most typical semantic role of a subject in a clause that has a direct object is that of the AGENTIVE participant: that is, the animate being instigating or causing the happening denoted by the verb: 'Margaret is mowing the grass'(Quirk et al. 1985: 741)".

They also refer to "the roles ${ }^{3}$ of the subject, apart from its typical role as agentive" when they write:

"The subject sometimes has the role of EXTERNAL CAUSER; that is, it expresses the unwitting (generally inanimate) cause of an event: 
(b) The avalanche destroyed several houses

(c) The electric shock killed him.

It may also have the role of INSTRUMENT; that is, the entity (generally inanimate) which an agent uses to perform an action or instigate a process:

(d) A stone broke his glasses.

(e) A car knocked them down.

(f) The computer has solved the problem (Quirk et al. 1985: 743) ${ }^{4}$.

IV. How would one interpret/translate the example sentences (b)-(f) referred to above? The avalanche, electric shock, stone, car and computer are all inanimate things. As such, a Japanese speaker would find it difficult to perceive of them (Kondo 1986: 14) 5 as performing acts or actions of their own volition. Japanese transitive verbs normally have animate things as subjects, and are used, as I have already mentioned, when the speaker is conscious of the act or action of the subject as exerting control on or over an external object. Our interpretation must thus be amended to take this into account.

According to the analysis by Quirk et al. (1985), the inanimate subjects in the sentences (b)-(f) can be regarded as being the cause of the perceived happenings, or as being the instruments/means to an end, and accordingly must be treated in Japanese as adverbial phrases (Kunihiro 1967: 161). Similarly, the objects of the sentences (b)-(f) have to be identified in these cases as being the Japanese subjects of the actions or events. In this situation, the use of transitive verbs is not possible - we are required to make appropriate predicates, mostly by intransitive counterparts of the transitive verbs used in the English sentences or their passive forms, so that the effect of the cause or the means is expressed. The diagram below shows the typical transformation pattern:

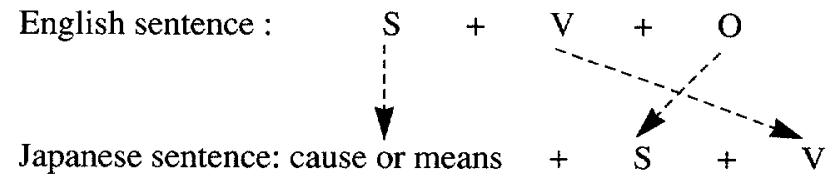

Taking all of this into consideration, the sentences (b)-(f) are adjusted and interpreted as follows:

(b) original: The avalanche destroyed several houses.

adjusted: Because of the avalanche, several houses were destroyed.

Japanese: Nadare de ie ga nanken ka kowareta.

(c) original: The electric shock killed him. adjusted: Because of the electric shock, he was killed. Japanese: Denki shokku de sono hito wa shinda.

(d) original: A stone broke his glasses. adjusted: With a stone, his glasses were broken. Japanese: Ishi de sono hito no megane wa kowareta.

(e) original: $A$ car knocked them down. adjusted: $\boldsymbol{B y}$ a car, they were knocked down. Japanese: Kuruma ni sono hitotachi wa hikitaosareta.

(f) original: The computer has solved the problem. adjusted: By the computer, the problem has been solved. Japanese: Kompyuta de sono mondai wa kaiketsu-shita. 
$\mathrm{V}$. We see the inanimate subject sentence as representing the inevitable correlation between the cause and the effect and the one between the means and the effect. Therefore, the English inanimate subject must be converted to an adverbial phrase or clause so as to make it denote its role as such. The adverbial phrase or clause can be constructed by the use of the following expressions:

de: this particle is used in the sentences (b), (c), (d) and (f) quoted earlier.

ni: this particle is used when the Japanese subject is a recipient of the effect of an event. It is used in the sentence (e) quoted earlier.

ni yotte/ni yori: it is more emphatic than the particles "de" and "ni" referred to above. It is usually used when an action of general or abstract nature is described. It is also used when an action undertaken for something or a concept of abstract nature is described objectively.

Quirk et al. (1985: 1278) draw attention to the question of direction of predications, which will be useful for handling compound inanimate subjects:

"The variable 'direction' of predications which correspond to noun phrases postmodified by of contributes greatly to the complexity of these expressions and has a bearing on the correspondence with the genetive. If we look at it in this way, we have left-to-right predication in the following:

the imprisonment of the murderer

- (someone) imprisoned the murderer [1]

a woman of courage

- the woman has courage $[2$

We have right-to-left predication in:

the arrival of the train ] the train

the train's arrival ] arrived [3]

the funnel of the ship - the ship has a funnel [4]

With the left-to-right example [1] and [2], it seems reasonable to assume a verbobject relationship; similarly, the right-to-left examples [3] and [4] show a subject-verb relationship. These relations are more obvious in [1] and [3], where the heads are deverbal nouns, than in [2] and [4], where the predicational relationship is covert or implicit "(Quirk et al. 1985: 1278).

If the English subject is a compound one, for example, comprised of two or more nouns, particularly when one stems from a verb, or is comprised of a noun and an adjective, participle, or a numeral, we can transform it to an adverbial clause, by predication, with the use of the grammatical expressions such as "to", "tara". "node", "tame (ni)", and "niwa".

(g) original: The strategic location of natural resources throughout the state ensures that the existing pattern of regional development will continue.

adjusted: As the natural resources are located strategically throughout the state, we are assured that the existing pattern of regional development will continue.

Japanese: Tennen shigen ga shu zenpan ni watatte kojoken de nemutte iru node, genzai okonatte iru chiiki kaihatsu wa hikitsuzuite shinten suru koto ga kakujitsu da to omowareru. 
We have right-to-left predication which assumes a subject-verb relationship; the inanimate subject expressing the location, existence or presence is modified so that it can denote cause/reason in Japanese; "the strategic location" in the original serves as the predicate in the modified Japanese sentence.

(h) original: Complete analysis of this problem requires a computer program. adjusted: To analyse this problem completely, we require a computer program. Japanese: Kono mondai o kanzenni bunseki-suru niwa, kompyuta puroguramu ga hitsuyo de aru.

Here we have left-to-right predication which assumes a verb-object relationship. Because of the verb "require" we regard the inanimate subject as denoting a general approach.

(i) original: A slight slip of the doctor's hand would mean a total disaster. adjusted: Should the doctor's hand slip even slightly, a total disaster would occur. Japanese: Isha no te ga wazuka demo subettara okina fuko o maneku koto ni naro.

We have right-to-left predication which assumes a subject-verb relationship. The English subjunctive sentence is interpreted/translated into Japanese with the use of the "tara" by which the consequence of an event is stressed.

(j) original: This centralised marketing set-up will enable us to give much better service than otherwise has been the case.

adjusted: When the marketing set-up is centralised in this way, we will be able to give much better service than otherwise have been the case.

Japanese: Kono yoni hanbai soshiki o tokatsu-suru to tokuisaki ni taisuru sabisu o sarani jujitsu-saseru koto ga dekiru yoni naro.

For this participle + noun structure we have right-to-left predication which assumes a subject-verb relationship.

(k) original: A walk of some two hundred metres brought us to the station.

adjusted: After we walked some two hundred metres we found ourselves at the station.

Japanese: Nihyaku metoru bakari aruite iku to eki ni deta.

We have left-to-right predication.

VI. The following three sentences (1), (m), and (n) comprise the sentence (a) which we were dealing with earlier:

(1) original: A shortage of seats limited the number of Japanese tourists who are able to make the trip.

adjusted (version 1): As available seats were insufficient, the number of Japanese tourists who are able to make the trip was limited.

Japanese (version 1): (Hikoki no) zaseki ga tarinai tame ni ryoko ni ikeru nipponjin kankokyaku no kazu ni gendo ga atta.

We have right-to-left predication which assumes a subject-adjective relationship. The "tame ni" which expresses a cause objectively serves to make the statement formal, and often appears in the written style.

If we want to deal with the modified word ("Japanese tourists") first and then the modifying clause ("who are able to make the trip") as in the order of the English original, that modifying clause must be converted to one of opposite meaning using the negative so as to make it correspond with the overall context: 
adjusted (version 2): As available seats were insufficient the number of Japanese tourists was limited, preventing many from making the trip, even though they wanted to. Japanese (version 2): (Hikoki no) zaseki ga tarinai tame ni nipponjin kankokyaku no kazu ni gendo ga ari, ryoko ni ikitakute mo ikenaku natte shimau no de aru.

(m) original: A shortage of seats prevented an even more spectacular increase. adjusted: As the number of seats was insufficient, we were precluded from witnessing an even more spectacular increase.

Japanese: (Hikoki no) zaseki ga tarinai tame ni (kankokyaku no) hiyakutekina nobi wa nozomenaku natta.

(n) original: A more spectacular increase would have created more employment opportunities.

adjusted (version 1): If an increase had been more spectacular, more employment opportunities would have been created.

We have right-to-left predication which assumes a subject-adjective relationship:

Japanese (version 1): (Kankokyaku no) nobi ga motto hiyakutekina mono dattanara, koyo kikai ga sarani zodai-shite ita daro.

This last subjunctive sentence can be rewritten in an actual sense, which is exactly the opposite from the original:

adjusted (version 2): Because an increase was not more spectacular, no more employment opportunities could be created.

Japanese (version 2): (Kankokyaku no) nobi ga hiyakutekina mono dewa nakatta tame ni, koyo kikai ga sarani zodai-suru to iu yona koto mo nakatta no de aru.

VII. In order to complete the task of interpreting/translating sentence (a) below, which was proposed at the outset of this paper, we can now put the three Japanese sentences $(1),(\mathrm{m})$, and (n) together:

(a) original:A shortage of seats ${ }^{\mathrm{NP} 1}$ [which limited the number of Japanese tourists who are able to make the trip] prevented an even more spectacular increase ${ }^{\mathrm{NP} 2}$ [that would have created more employment opportunities.]

adjusted (version 1): As available seats were insufficient, the number of Japanese tourists who are able to make the trip was limited, and consequently made it impossible for us to witness an even more spectacular increase. Otherwise (if all had gone well), more employment opportunities would have been created.

Japanese (version 1): (Hikoki no) zaseki ga tarinai tame ni ryoko ni ikeru nipponjin kankokyaku no kazu ni gendo ga ari, (kankokyaku no) hiyakutekina nobi wa nozomenaku narimashita. Moshi juntoni itte itara, koyo kikai ga sarani zodaishite ita desho.

adjusted (version 2): As available seats were insufficient, the number of Japanese tourists was limited, and this prevented them from making the trip, even though they wanted to. It thus became impossible for us to witness an even more spectacular increase, and this meant that no more employment opportunities could be created.

Japanese (version 2): (Hikoki no) zaseki ga tarinai to nipponjin kankokyaku no kazu ni gendo ga ari, ryoko ni ikitakute mo ikenaku naru tame (ni) (kankokyaku no) hiyakutekina nobi wa nozomenaku nari, koyo kikai ga sarani zodai-suru to iu yona koto mo arienaku naru wake desu.

The processing of the inanimate subjects was successfully undertaken first, followed by the noun phrases, the subjects of which were also inanimate.

With regard to the original English sentence (a) which contains three relative clauses including the one whose subject is animate, it turns out that each clause can be 
consecutively interpreted/translated one clause after another, although it requires a high level of skill to do so.

VIII. The merit in the modification of an English inanimate subject to a Japanese adverbial phrase is particularly significant in the following respects:

(i) it enables the interpreter/translator dealing with a sentence with a modifying clause, the subject of which is also inanimate, to undertake the processing of the inanimate subject first, followed by the modifying clause or phrase as in the order of the original sentence.

(ii) it serves to assist memory retention, especially when the interpreter/translator deals with a sentence with a modifying clause, because it acts as the agent that determines overall relationships with what follows after.

(iii) it corresponds with the Japanese perception of sentence structure and enables the listener/reader to comprehend readily.

This all has relevance to interpreting and interpreter training also. However, further work needs to be done in regard to the many problems associated with modifying clauses, especially relative clauses. There are also many other problems arising from the differences of word order and language perceptions between English and Japanese speakers, which include those connected with possessive case, passive voice, subjunctive mood, speech, and so on. Skills for overcoming those problems are yet to be developed, and there is room for much further research.

\section{NOTES}

1. Some parts of the preface and poems (such as numbers $165,91,94,212,243,277$ ) of the Kokinshu, the first imperial anthology of Japanese poetry, compiled in A.D.905.

2. Kondo also pointed out (p. 11-12) that the Japanese also neglected research in this area.

3. Kondo (1986: 14) pointed out that there was one exceptional type of subject which Quirk et al. suggested by this comment: "The tendency towards a metaphorical perception of agentiveness in nonagentive subjects, as used in everyday language, is conspicuous in examples such as: "Guns kill"; "matches start fires"; "a car drove by"; and "the door refused to open." (Kondo 1986 cited in Quirk et al. 1985: 745)

4. Note: Letters (b), (c), (d), (e) and (f) labelled before each of the example sentences were added by the author.

5. With regard to the sentences (b), (e) and (f), Kondo (1986: 14) suggests that it will be possible to interpret them in Japanese without any adjustment:

(b) Nadare ga ikutsuka no ie o kowashita.

(e) (Hashitte kita) kuruma ga sono hitotachi o nagitaoshita/hikitaoshita

(f) Kompyuta ga sono mondai [o kaiketsu-shite kureta.

[no kata o tsukete kureta.

\section{BIBLIOGRAPHY}

CHOMSKY, N. (1965): Aspects of the Theory of Syntax, MIT Press, Massachusetts Institute of Technology, Cambridge, Massachusetts, p. 16.

KONDO, M. (1986): "Eigo ni okeru museibutsu shugo no yoho to shakai kagaku no hohoron (Inanimate subjects in English and the methodology of Social Science)", Daito Bunka Daigaku Kiyo, 24.

KUNIHIRO, T. (1967): "Kozoteki imiron", Sanseido, p. 161.

QUIRK, R., Greenbaum, S., Leech, G. and J. Svartrik (1985): Comprehensive Grammar of the English Language, London, Longman.

TOMII, A. (1988): "Techniques in Japanese to English and English to Japanese Translation", Language at Crossroads. Proceedings of the 29th Annual Conference, American Translators Association, Oct. 12-16, p. 181 . 